\section{Heading for the nineties}

\section{Washington}

US neuroscientists' attempts to turn a Congressional resolution designating the 1990 s the 'Decade of the Brain' into a financial reality gained a little help last week when US president George Bush signed a proclamation calling on the decade to be observed with "appropriate programmes", and the First Lady, Barbara Bush, opened a two-day meeting intended to publicize the start of the decade.

Both the National Institute of Mental Health (NIMH) and the National Institute of Neurological Disorders and Stroke (NINDS), the two institutes of the US Department of Health and Human Services most likely to benefit from increased efforts in neuroscience, have already released plans laying out what could be achieved in the decade.

The report from NINDS, released last month, also reveals what the decade might cost — for NINDS alone an initial increase of $\$ 221$ million above the administration's $\$ 500$ million budget request, followed by a further rise of similar size two years from now.

Funding requests on this scale need a compelling argument if they are to make it through Congress. At last week's 'Decade of the Brain' meeting at the National Academy of Sciences, the logic came in two parts. At the meeting were a selection of the finest neuroscientists working in the United States, speaking in a programme that ran from work on ion channels to neural-network computing. These scientists delivered the first part of the message - that neuroscience is now a mature discipline in the sense that it contains areas in which it is fairly evident what needs to be done and, broadly speaking, how to do it. What that means is that Congress and president can be sure that increased investment will translate directly into increased results.

Areas where the prospects for rapid progress are good were listed by NIMH in a document given out at the meeting: they include the identification and cloning of the genes responsible for schizophrenia, manic-depressive illness, Alzheimer's disease and other mental illnesses; the detailed mapping of where various neurotransmitters and receptors act within the brain; the use of computer-analysed brain activity measurements in improved diagnosis of brain disorders, and use of models of receptor structure to design and synthesize drugs that could help treat conditions, such as schizophrenia, that are thought to be to due to defects in neurotransmission.

The second part of the logic, presented most graphically by Lewis Judd, director of the National Institute of Mental Health is that mental illnesses are a gigantic burden for the health-care system. Judd points out that some $15-20$ per cent of people are affected by some form of mental illness each year. The Congressional proclamation estimates that in the United States, the "treatment, rehabilitation and related costs of disorders and disabilities that affect the brain represents a total economic burden of $\$ 305,000$ million annually". Investment in basic research to produce more effective forms of treatment thus has the potential for generating a large return.

"If you combine the costs of 50 million people a year suffering from mental disorders with a science that is growing exponentially then you have a potentially convincing argument that we're hoping will carry the day, and that funding will flow from it", says Judd. He and his fellow institute directors are not themselves permitted to lobby for increased funds; the job, he says, will have to be performed by the many patient groups (the Cerebral Palsy Foundation, the Epilepsy Foundation and so on) as well as the various professional and scientific societies. A first move of this kind was announced at the conference by David Mahoney, a director of the Dana-Farber Foundation. The foundation is to set up an institute to lobby for support for the decade, and a $\$ 25,000$-a-year prize to be offered each year of the decade to an outstanding neuroscientist.

Are president and Congress going to be persuaded to support the decade? The House of Representatives has already given mention of the Decade of the Brain as an "area of special concern" in its 1991 appropriations bill for the Department of Health and Human Services, but there will be very little new money available this year. A panel discussion at the conference which included Allan Bromley, White House Science Advisor, James Mason, Assistant Secretary for Health, and Frederick Goodwin, administrator of the Alcohol, Drug Abuse and Mental Health Administration, raised few hopes that riches were about to be showered on neuroscientists. Although steps are being taken to set up a coordinating committee within the White House, most talk at the conference was of the gloomy prospects presented by the growing federal budget deficit.

The next public event in the Decade of the Brain will be the start of a Library of Congress lecture series sponsored by the National Institute of Mental Health. The lectures will continue throughout the decade, with clusters of six lectures each autumn and spring. The first lecture, appropriately enough, will focus on the cost to the United States of brain-related disorders.

Alun Anderson

\section{Pyrrhic victory in South Pacific}

\section{Sydney \& Tokyo}

UNDER pressure from Australia and other South Pacific nations Japan announced last week in Canberra that it will suspend drift-net fishing in the South Pacific a year earlier than required by a United Nations resolution. But the decision will have little overall effect on Japan's drift-net operations, which are based largely in the North Pacific.

Drift-net fishing, which employs sets of nets up to $60 \mathrm{~km}$ in total length to catch tuna and squid, has been condemned because it kills other marine life indiscriminately, in particular turtles, seabirds and dolphins. Last year the United Nations adopted a resolution, endorsed by Japan, that bans the technique in the South Pacific from 1 July 1991 and worldwide a year later, unless it is deployed using proven management techniques.

Japan's suspension will come into effect in October, the beginning of this year's season. But, as pointed out by Peter Gill of Greenpeace, "Japan has withdrawn less than thirty boats from the [South Pacific] region while they maintain over one thousand boats in the North Pacific". The South Pacific decision is "chicken feed" compared with the North, Gill says, and he doubts that the UN resolution will bring about a worldwide ban by 1992 .

Tania Ewing \& David Swinbanks

\section{Wildlife response to the nets}

\section{Washington}

THE US National Marine Fisheries Service (NMFS) finally agreed earlier this month to release some of the data they have collected on the impact of drift-net fishing on marine life after a meeting between Congresswoman Jolene Unsoeld (Democrat Olympia) and the director of NMFS. Unsoeld has been campaigning for a ban on the technique. The data come from a survey conducted last year by US, Canadian and Japanese observers on board some of the $\mathbf{4 7 0}$ licenced Japanese drift-net boats that catch squid in the North Pacific during the summer months.

Observers looked at a total of 1,402 'sets' of the net - about one fiftieth of the total - in each case examining about threequarters of the catch. They found that the nets had caught 208 fur seals, 914 dolphins, 22 turtles, 539 albatrosses, 8,536 shearwaters, 25 puffins (an endangered group) and 17 storm petrels. NMFS officials are not yet ready to say what impact this level of mortality might have on the total population of North Pacific sea mammals, turtles and birds. A more detailed survey is being carried out this year with three times as many observers aboard the fishing boats. Alun Anderson 